\title{
Essential Function of Oncostatin M in Nociceptive Neurons of Dorsal Root Ganglia
}

\author{
Yoshihiro Morikawa, ${ }^{1 *}$ Shinobu Tamura, ${ }^{1 *}$ Ken-ichi Minehata, ${ }^{2}$ Peter J. Donovan, ${ }^{3}$ Atsushi Miyajima, ${ }^{2,4}$ and \\ Emiko Senba ${ }^{1}$ \\ ${ }^{1}$ Department of Anatomy and Neurobiology, Wakayama Medical University, Wakayama, 641-8509 Japan, ${ }^{2}$ Laboratory of Cell Growth and Differentiation, \\ Institute of Molecular and Cellular Bioscience, University of Tokyo, Bunkyo-ku, Tokyo, 113-0032 Japan, ${ }^{3}$ Kimmel Cancer Center, Thomas Jefferson \\ University, Philadelphia, Pennsylvania 19107, and ${ }^{4}$ Core Research for Evolutional Science and Technology, Japan Science and Technology Corporation, \\ Kawaguchi 322-0012 Japan
}

Oncostatin M (OSM) is a member of the interleukin-6 family of cytokines, and we have reported previously that the murine 0SM receptor $\beta$ subunit (OSMR) was expressed in some neurons in the adult trigeminal and dorsal root ganglia (DRGs) and in the perineonatal hypoglossal nucleus. In the present study, we investigated the development of OSMR-positive neurons of DRGs in OSM-deficient mice. In situ hybridization revealed that OSMR-positive neurons in DRGs began to appear at postnatal day 0 (P0) and reached the adult level at P14. In the DRGs of the OSM-deficient mice, vanilloid receptor 1 (VR1)- and P2X3-positive small-sized neurons were significantly decreased. In addition, OSMR-positive neurons decreased, resulting in the reduced number of VR1/P2X3/0SMR-triple positive neurons. OSM-deficient mice displayed significantly reduced noxious responses in models of acute thermal, mechanical, chemical, and visceral pain. Thus, OSM plays an essential role in the development of a subtype of nociceptive neurons in the DRGs.

Key words: oncostatin M; receptor; dorsal root ganglion; Ret; VR1; P2X3; mouse; gene-targeting; pain; behavior

\section{Introduction}

Oncostatin M (OSM) is a member of the interleukin-6 (IL-6) family of cytokines that includes IL-6, IL-11, leukemia inhibitory factor (LIF), ciliary neurotrophic factor, cardiotrophin-1, and novel neurotrophin-1/B-cell stimulatory factor-3/cardiotrophin-like cytokine (Taga and Kishimoto, 1997; Heinrich et al., 1998; Senaldi et al., 1999; Elson et al., 2000). These cytokines play important roles in hematopoiesis, inflammation, regulation of the acute phase responses, bone remodeling, heart development, and neurogenesis. Human OSM was originally isolated from a phorbol esterstimulated human histiocytic lymphoma cell line (Zarling et al., 1986). Although the mouse OSM gene had long been unidentified, its cDNA has been cloned recently as a cytokine-inducible early response gene (Yoshimura et al., 1996).

A unique feature of the IL- 6 family is their redundant activities, which are attributed to the shared use of glycoprotein (gp) 130 , the common signal-transducing subunit of the receptors for these cytokines (Kishimoto et al., 1995). OSM induces signals through the receptor complex comprising gp130 and the OSM-

Received Sept. 29, 2003; revised Dec. 5, 2003; accepted Dec. 6, 2003.

This work was supported by a Grant-in-Aid for Scientific Research (C) from The Ministry of Education, Culture, Sports, Science and Technology (15500264) and a Research Grant on Primary Areas from Wakayama Medical University. We thank Prof. Masahide Takahashi (Department of Pathology, Nagoya University School of Medicine, Nagoya, Japan) for the gift of the c-Ret antiserum.

*Y.M. and S.T. contributed equally to this work.

Correspondence should be addressed to Dr. Yoshihiro Morikawa, Department of Anatomy and Neurobiology, Wakayama Medical University, 811-1 Kimiidera, Wakayama, 641-8509 Japan. E-mail: yoshim@wakayama-med.ac.jp.

D01:10.1523/JNEUROSCI.4975-03.2004

Copyright $\odot 2004$ Society for Neuroscience $\quad 0270-6474 / 04 / 241941-07 \$ 15.00 / 0$ specific $\beta$ subunit (OSMR; Mosley et al., 1996; Heinrich et al., 1998). Recently, OSM-specific biological activities mediated through the OSMR, distinct from those of the other IL-6 family of cytokines, have been reported: the proliferation of multipotent hematopoietic progenitors and the formation of endothelial cell clusters possibly by stimulating their common precursors in vitro (Mukouyama et al., 1998; Miyajima et al., 2000), the differentiation of hepatocytes (Kamiya et al., 1999; Miyajima et al., 2000; Matsui et al., 2002), and the expansion of neonatal Sertoli cells (Hara et al., 1998).

We have reported previously that OSMR was widely expressed in various organs, including the nervous system, during murine embryogenesis and in the adult mice (Tamura et al., 2002a, 2003a,b). In dorsal root ganglia (DRGs), OSMR was shown to be expressed in nonpeptidergic nociceptive neurons, which expressed both the vanilloid receptor 1 (VR1) and the P2X3 purinergic receptor (Tamura et al., 2003a). Of the IL-6 family members, OSM and LIF are the most closely related functionally, structurally, and genetically (Gearing, 1993; Gearing et al., 1993; Jeffery et al., 1993). In the peripheral nervous system, LIF is required for the survival and differentiation of embryonic sensory neurons and the appropriate changes in neuronal gene expression after nerve injury (Sun and Zigmond, 1996; Lecomte et al., 1998; Turnley and Bartlett, 2000). During inflammation in peripheral tissues, LIF plays a key role in early anti-inflammatory responses, and exogenous LIF can reduce inflammatory hyperalgesia (Banner et al., 1998). On the other hand, Sugiura et al. (2000) have reported that inflammatory cell infiltration into crushed nerve is significantly slower in LIF knock-out mice. IL-6 is also essential for the maintenance of function and regeneration 
of sensory neurons (Zhong et al., 1999). Although there are many reports that describe roles of IL- 6 family cytokines in the murine peripheral nervous system, little is known about the role of OSM in adult mice. In the present study, we describe the involvement of OSM in the development of a specific subset of nociceptive neurons in murine DRGs.

\section{Materials and Methods}

Tissue preparation. Embryonic [embryonic day 11.5 (E11.5), E14.5, and E17.5], postnatal [postnatal day 0 (P0), P7, and P14], and adult (8 weeks old) C57BL/6J male mice (Nihon SLC, Hamamatsu, Japan) were used in the present study. The embryos were removed by cesarean section and immersed in ice-cold $0.1 \mathrm{M}$ phosphate buffer $(\mathrm{PB})$ containing $4 \%$ paraformaldehyde (PFA) at $4^{\circ} \mathrm{C}$ overnight. The postnatal and adult mice were perfused transcardially with ice-cold $0.85 \% \mathrm{NaCl}$ followed by ice-cold Zamboni's fixative (2\% PFA and $0.2 \%$ picric acid in $0.1 \mathrm{M} \mathrm{PB}, \mathrm{pH} 7.4$ ) for immunohistochemical staining or 4\% PFA in $0.1 \mathrm{~m}$ PBS for in situ hybridization. All perfusion fixations were performed under deep anesthesia (diethylether). DRGs (L4/L5) and spinal cord were quickly removed, followed by postfixation at $4^{\circ} \mathrm{C}$ for $3 \mathrm{hr}$ and finally $20 \%$ sucrose in $0.1 \mathrm{M}$ PBS. They were then embedded in OCT medium (Miles, Elkhart, IN) and frozen rapidly in cold n-hexane on dry ice and stored at $-80^{\circ} \mathrm{C}$.

The experiments were performed under the control of the Animal Research Control Committee in accordance with the Guidelines for Animal Experiments of Wakayama Medical University and Japanese Government Notification on Feeding and Safekeeping of Animals (No. 6). All efforts were made to minimize the number of animals used and their suffering.

Preparation of RNA probe. A 275 bp Asp718-XhoI cDNA fragment (coding region) of OSMR was ligated into a pBluescript II SK $(-)$ vector, which was then linearized by cutting with Asp718 (for the antisense probe) or with XhoI (for the sense probe). In vitro transcription was performed using appropriate RNA polymerase (T3 RNA polymerase for the antisense probe; T7 RNA polymerase for the sense probe) and $\left[\alpha-{ }^{35} \mathrm{~S}\right]$ UTP.

In situ hybridization analysis. In situ hybridization was performed as described previously (Tamura et al., 2002a, 2003b). Briefly, frozen sections were cut on a cryostat at $6 \mu \mathrm{m}$ thickness. After being hybridized at $55^{\circ} \mathrm{C}$ for $16 \mathrm{hr}$ with sense and antisense ${ }^{35} \mathrm{~S}$-labelled cRNA probes, the slides were submersed with Kodak NTB-2 liquid emulsion (Kodak, Rochester, NY). The dipped autoradiograms were developed 14 days later and fixed. The sections were counterstained through the emulsion with hematoxylin and eosin, and examined under bright- and dark-field microscopy (XF-WFL, Nikon, Tokyo, Japan).

Immunohistochemical method. Immunohistochemical staining was performed as described previously (Tamura et al., 2003a,b). Slidemounted 6- $\mu \mathrm{m}$ cryostat tissue sections of DRGs (L4/L5) and $20-\mu \mathrm{m}$ sections of murine spinal cord were processed for immunohistochemical method. Sections were preincubated in $0.1 \mathrm{M}$ PBS containing $10 \%$ normal donkey serum at room temperature (RT) for $1 \mathrm{hr}$, and then incubated with primary antibodies containing $0.5 \%$ bovine serum albumin (BSA) and $0.3 \%$ Triton X-100 $\left(4^{\circ} \mathrm{C}\right.$, overnight). Primary antibodies were used at the following dilutions: goat anti-OSMR, 1:50 (Santa Cruz Biotechnology, Santa Cruz, CA); rabbit anti-VR1, 1:500 (Oncogene, San Diego, CA); rabbit anti-calcitonin gene-related peptide (CGRP), 1:1000 (Amersham, Arlington Heights, IL); rabbit anti-tyrosine kinase (TrkA), 1:100 (Upstate Biotechnology, Lake Placid, NY); rabbit anti-c-receptor tyrosine kinase (Ret), 1:100 (Tamura et al., 2003a); and guinea pig antiP2X3, 1:1000 (Neuromics, Minneapolis, MN). The next day, sections were washed in $0.1 \mathrm{M}$ PBS containing $0.1 \%$ Triton X-100, and were incubated in the Cy2/Cy3-conjugated secondary antibodies (Jackson ImmunoResearch, West Grove, PA), containing $2 \%$ normal mouse serum and $0.3 \%$ Triton X-100 [room temperature (RT), $1 \mathrm{hr}$ ], diluted 1:400. For the avidin-biotin complex method, after the incubation with primary antisera, the sections were incubated in biotinylated donkey anti-goat IgG (Jackson ImmunoResearch), diluted 1:400, containing $0.5 \%$ BSA and $0.3 \%$ Triton X-100 (RT, $1 \mathrm{hr}$ ). After washes with $0.1 \mathrm{M}$ $\mathrm{PBS}$, the sections were incubated with 7-amino-4-methylcoumarin-3- acetic acid-conjugated streptavidin (Jackson ImmunoResearch) in $0.1 \mathrm{M}$ PBS (RT, 1 hr). Immunofluorescence images were acquired using Nikon (Tokyo, Japan) VFM microscope with fluorescent attachment.

Quantitative analysis. For stereological cell counting, L4/L5 DRGs from four perfused mice were pooled and processed for sectioning. Entire DRGs were serially sectioned at $6 \mu \mathrm{m}$ and stained with NeuroTrace (Molecular Probes, Eugene, OR) at 1:500 dilution for $20 \mathrm{~min}$ or 4',6diamidino-2-phenylindole dihydrochloride for 5 min for nuclear staining after incubation with secondary antisera. After staining, color digitized images of each section were captured using an epifluorescence microscope (Eclipse E800; Nikon) equipped with a color 3CCD camera (C5810; Hamamatsu Photonics, Shizuoka, Japan). The number of fluorescently labeled cells was counted using Adobe Photoshop software (Adobe Systems, San Jose, CA) under observer-blind conditions.

To obtain unbiased estimates of total dorsal root ganglion (DRG) neurons (stained with NeuroTrace) and VR1- or P2X3-labeled neurons, the physical dissector principle was used to count neurons in a section (Coggeshall, 1992). Briefly, in each DRG, pairs of adjacent sections (reference section and look-up section) were compared. Within a measured area of the section, only neurons with clearly visible nuclei and nucleoli present in the reference section but not the look-up section were counted, and then the neuronal density [number of cells/(measured area $\times$ section thickness)] was calculated. For each DRG, every 10 th section was analyzed, starting with a randomly chosen section between 1 and 10 .

The cross-sectional area occupied by neurons was measured for the DRG (NIH Image, version 1.61), and the volume of each ganglion occupied by neurons $\left(\mu \mathrm{m}^{3} \times 10^{6}\right)$ was estimated from the area measurements, section thickness, and the total number of sections containing each ganglion. Total numbers of NeuroTrace-stained neurons and numbers of VR1- or P2X3-labeled neurons in the DRG then were determined by multiplying the neuronal density by the total DRG volume (Gundersen et al., 1988).

Cells were outlined manually using a computer mouse to measure the cell size, and cross-sectional areas for outlined cell profiles were quantified using NIH Image, version 1.61. Size-frequency histograms were then generated from counted neurons. The values shown are means \pm SEM. All statistical analyses were performed using Student's $t$ test. Significance was determined to be $p<0.05$.

Gene targeting the OSM locus. As described previously (M.P. de Miguel, J. M. Centanni, C. Stewart, T. Hara, K. Minehata, M. EmbreeKu, K. Boekelheide, A. Miyajima, and P. J. Donovan, unpublished observations), genomic clones hybridizing to the mouse OSM cDNA were obtained from a $\lambda$ phage $129 / \mathrm{Sv}$ mouse genomic library, which was partially digested with BamHI, MboI, BgIII, or Sau3AI. The targeting vector was constructed by cloning the selected $15.8 \mathrm{~Kb}$ clone containing the entire mOSM locus into a pJMM4 plasmid that contained a neomycin resistance cassette driven by the phosphoglycerate kinase (PGK) promoter. The gene targeting strategy was designed to replace the endogenous exon II and coding region of exon III as well as the intervening intron with the PGKNeo gene which introduces diagnostic XbaI and SphI sites into the genomic locus.

Southern analysis and/or PCR was used to genotype the offspring. For Southern analysis, the genomic DNA was digested with SphI and hybridized with a $5^{\prime}$ external probe ( $600 \mathrm{bp}$ long). The wild-type allele was detected as a $9 \mathrm{~kb}$ band, whereas the mutant allele generated a $7 \mathrm{~kb}$ band. For PCR genotyping, two sets of primers were used in the same reaction mixture. To amplify a $420 \mathrm{bp}$ fragment of the wild-type OSM allele (420 bp), primers OSMs (CAAGGGAACCCGCAGAATCTG) and OSMa (TGAATCAGCTTGTGTCATCAG) were used. To amplify a $585 \mathrm{bp}$ fragment from the Neo gene in the targeted locus the primers NEOs (GAACAAGATGGATTGCACGCAG) and NEOa (CCATGATATTCGGCAAGCAG) were used. The PCR conditions were $95^{\circ} \mathrm{C}$ for $2 \mathrm{~min}$ and 30 cycles of $94^{\circ} \mathrm{C}$ for $30 \mathrm{sec}, 59^{\circ} \mathrm{C}$ for $1 \mathrm{~min}$, and $72^{\circ} \mathrm{C}$ for $1 \mathrm{~min}$, with an extension cycle at $72^{\circ} \mathrm{C}$ for $10 \mathrm{~min}$.

$\mathrm{OSM}^{+/-}$males were backcrossed at least six generations to C57BL/6 females to place the OSM deficiency on a more nearly isogenic background. OSM ${ }^{+1+}$ and OSM ${ }^{-1-}$ littermate mice generated from heterozygous intercrosses were used for all experiments. 
Behavioral tests. These experiments were approved by the Wakayama Medical University Animal Care and Use Committee.

Chemical nociception was assessed by the capsaicin, $\alpha \beta$-methylene ATP $(\alpha \beta$-meATP), and formalin tests (Dickenson and Sullivan, 1987; Cao et al., 1998; Caterina et al., 2000; Tsuda et al., 2002). For $4 \mathrm{~d}$ before these tests, mice were acclimated on the test platform for $2 \mathrm{hr}$ every day. On the day of the study, mice were placed on the test platform for $1 \mathrm{hr}$ and subsequently were administered $10 \mu \mathrm{l}$ of capsaicin (1-5 mg in $10 \mathrm{ml}$ saline $/ 10 \%$ ethanol $/ 0.5 \%$ Tween 80 ; Sigma-Aldrich, St. Louis, MO), 10 $\mu \mathrm{l}$ of $\alpha \beta$-meATP (Sigma , $10 \mu \mathrm{mol} / \mathrm{ml}$ ), and $10 \mu \mathrm{l}$ of $5 \%$ formalin in the plantar surface of the left paw for each tests. The time spent either licking or lifting the injected paw was recorded. In the hot-plate assay (Cao et al., 1998; Caterina et al., 2000), mice were first habituated to the hot-plate apparatus with temperature set at $45^{\circ} \mathrm{C}$ for $2 \mathrm{~min}$. Subsequently, mice were placed on the hot plate $\left(48-58^{\circ} \mathrm{C}\right)$ and the response latency to hindpaw licking or to jumping was recorded. The cutoff time was $60 \mathrm{sec}$ for the $52^{\circ} \mathrm{C}$ hot plate and $30 \mathrm{sec}$ at $58^{\circ} \mathrm{C}$. Mechanical sensitivity was assessed by the tail-pinch test (Cao et al., 1998). We determined the latency to respond (lick or bite) to an intense mechanical stimulus by a clip applied to the tail. Responses to visceral stimuli were assessed as the number of abdominal stretches after intraperitoneal injections of $0.6 \%$ acetic acid ( $5 \mathrm{ml} / \mathrm{kg}$; visceral pain with inflammation) or $\mathrm{MgSO}_{4}(120$ $\mathrm{mg} / \mathrm{kg}$; visceral pain without inflammation) (Cao et al., 1998). The frequency of stretch responses was counted for $20 \mathrm{~min}$ for acetic acid or for $5 \mathrm{~min}$ for $\mathrm{MgSO}_{4}$. Motor function was assessed by using an accelerating Rotarod treadmill (Ugo Basile, Comerio, Italy). The mice are first trained to walk on the rotating rod for $3 \mathrm{~min}$ at a speed of $4 \mathrm{rpm}$. For testing, the speed was set at $4 \mathrm{rpm}$ and subsequently accelerated to $40 \mathrm{rpm}$. The time taken for mice to fall after the beginning of the acceleration was recorded.

\section{Results}

\section{Developmental expression patterns of OSMR in}

\section{DRG neurons}

To examine the developmental expression pattern of OSMR in DRGs, lower lumber DRGs at developmental ages E14.5 to P14 were hybridized to identify neurons expressing OSMR mRNA. OSMR mRNA was not detected in any cells of the DRGs during the embryonic stages (data not shown). OSMR mRNA was first detected in a few cells of the DRGs at P0, gradually increased, and reached the adult level at P14 (Fig. 1).

\section{Decrease of a subset of nociceptive DRG neurons in adult OSM $^{-1-}$ mice}

To help define the role of OSM in the development of the mouse DRGs, we used OSM-deficient mice. OSM ${ }^{-1-}$ mice developed normally, and were not distinguishable from their $+/+$ or $+/-$ littermates in terms of size or weight at any point during their development (data not shown). As described previously (Tamura et al., 2003a), 13\% of total DRG neurons in normal adult mice were OSMR-positive small-sized neurons, which expressed VR1 and P2X3. Immunohistochemical staining for sensory neuronal markers revealed that the numbers of VR1-positive $\left(\mathrm{OSM}^{+/+}\right.$, $\left.46.8 \pm 1.4 \% \mathrm{OSM}^{-1-}, 24.0 \pm 1.0 \% ; p<0.001\right)$ and $\mathrm{P} 2 \mathrm{X} 3-$ positive $\left(\mathrm{OSM}^{+/+}, 56.3 \pm 0.9 \%\right.$; $\mathrm{OSM}^{-/-}, 46.5 \pm 1.2 \%$; $p<$ $0.001)$ DRG neurons were significantly reduced in the DRGs of the adult $\mathrm{OSM}^{-1-}$ mice (Fig. 2). We could not detect significant changes in the number of TrkA- and c-Ret-positive neurons. No changes in the CGRP-positive DRG neurons were also observed in the adult $\mathrm{OSM}^{-1-}$ mice (Fig. 2). In addition, analysis of size frequency of total, VR1-positive, and P2X3-positive neurons showed the decrease in the small-sized neurons, which expressed VR1 and P2X3 (Fig. 3), in the DRGs of OSM ${ }^{-1-}$ mice.

In a previous report (Tamura et al., 2003a), we demonstrated that all OSMR-positive neurons were VR1/P2X3-doublepositive. Double-immunofluorescence staining for VR1 and
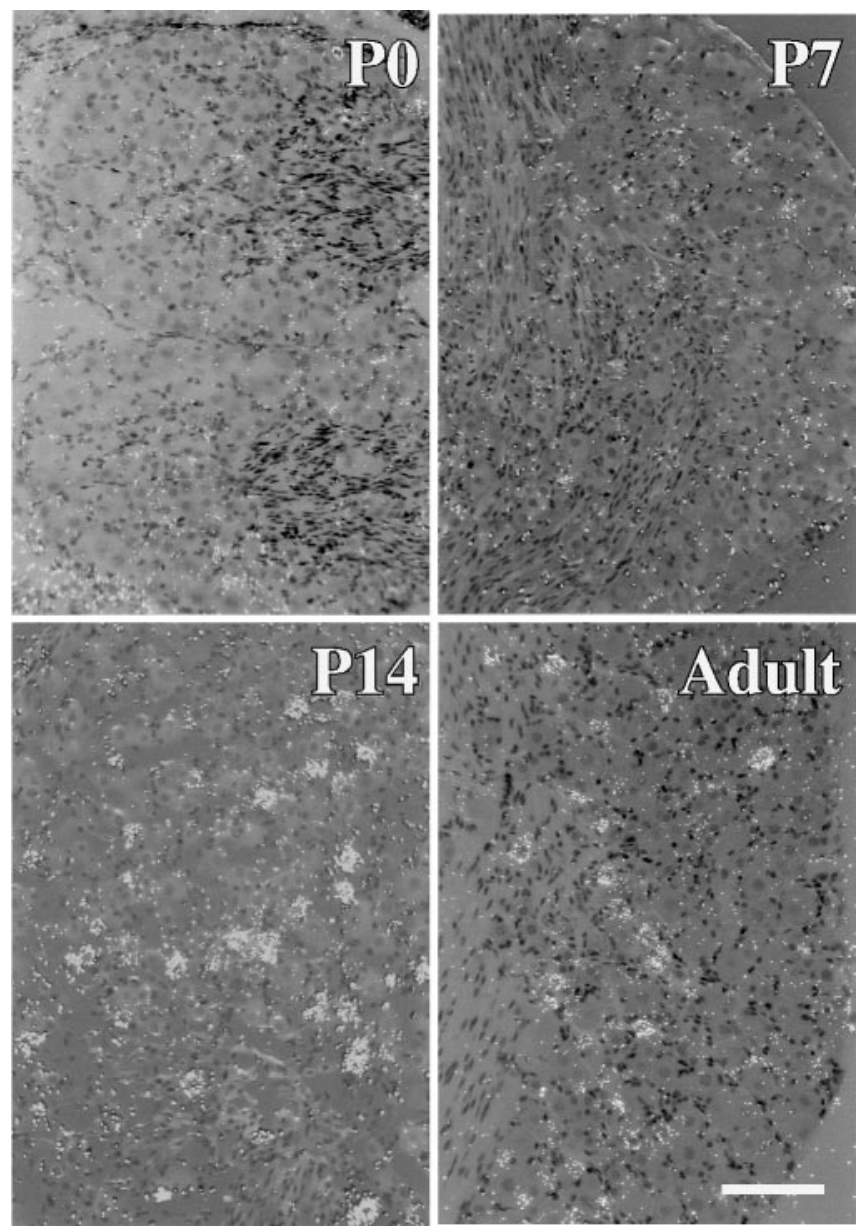

Figure 1. In situ hybridization for the detection of OSMR $m R N A$ in developing DRGs at the indicated stages (P0, P7, P14, and adult). A progressive increase in the number of OSMRpositive neurons during early postnatal development was observed. Scale bar, $100 \mu \mathrm{m}$.

$\mathrm{P} 2 \mathrm{X} 3$ revealed significant reduction of VR1/P2X3-doublepositive neurons of DRGs in OSM ${ }^{-1-}$ mice (Fig. 4, arrowheads) OSM $^{+/+}, 26.4 \pm 1.8 \%$ OSM $^{-/-}, 7.8 \pm 1.3 \%$; $\left.p<0.01\right)$. In addition, OSMR-positive DRG neurons were also decreased in $\mathrm{OSM}^{-1-}$ mice (OSM $^{+/+}, 15.2 \pm 1.8 \%$ OSM $^{-1-}, 7.6 \pm 0.6 \%$; $p<0.03$ ), resulting in the reduced VR1/P2X3/OSMR-triplepositive neurons.

To define the laminar localization of VR1 and P2X3 in adult lumbar spinal cord in $\mathrm{OSM}^{-1-}$ mice, we performed doubleimmunofluorescence staining for VR1 and P2X3. The primary afferent fibers expressing VR1 (Fig. 5, green) and P2X3 (Fig. 5, red) are known to be distributed within lamina I-II and within the inner portion of lamina II (lamina IIi), respectively. As shown in Figure 5, in OSM ${ }^{-1-}$ mice, we could detect few VR1/P2X3double-positive fibers (yellow) within the lamina IIi of the spinal cord, which were clearly detected in $\mathrm{OSM}^{+/+}$mice.

\section{Defects in pain sensitivity in adult $\mathrm{OSM}^{-/-}$mice}

$\mathrm{OSM}^{-1-}$ mice did not exhibit any impairment of motor coordination; retention times using the Rotarod test were $98 \pm 6.1 \mathrm{sec}$ for $\mathrm{OSM}^{+/+}$mice and $104 \pm 4.7 \mathrm{sec}$ for $\mathrm{OSM}^{-1-}$ mice $(n=6$ per group).

To assess nociceptive function experimentally, we performed a battery of behavioral tests on adult OSM ${ }^{-1-}$ mice (Fig. 6). First, we assessed the nociceptive responses to chemical stimuli, including capsaicin, $\alpha \beta$-meATP, and formalin, because the VR1- and 


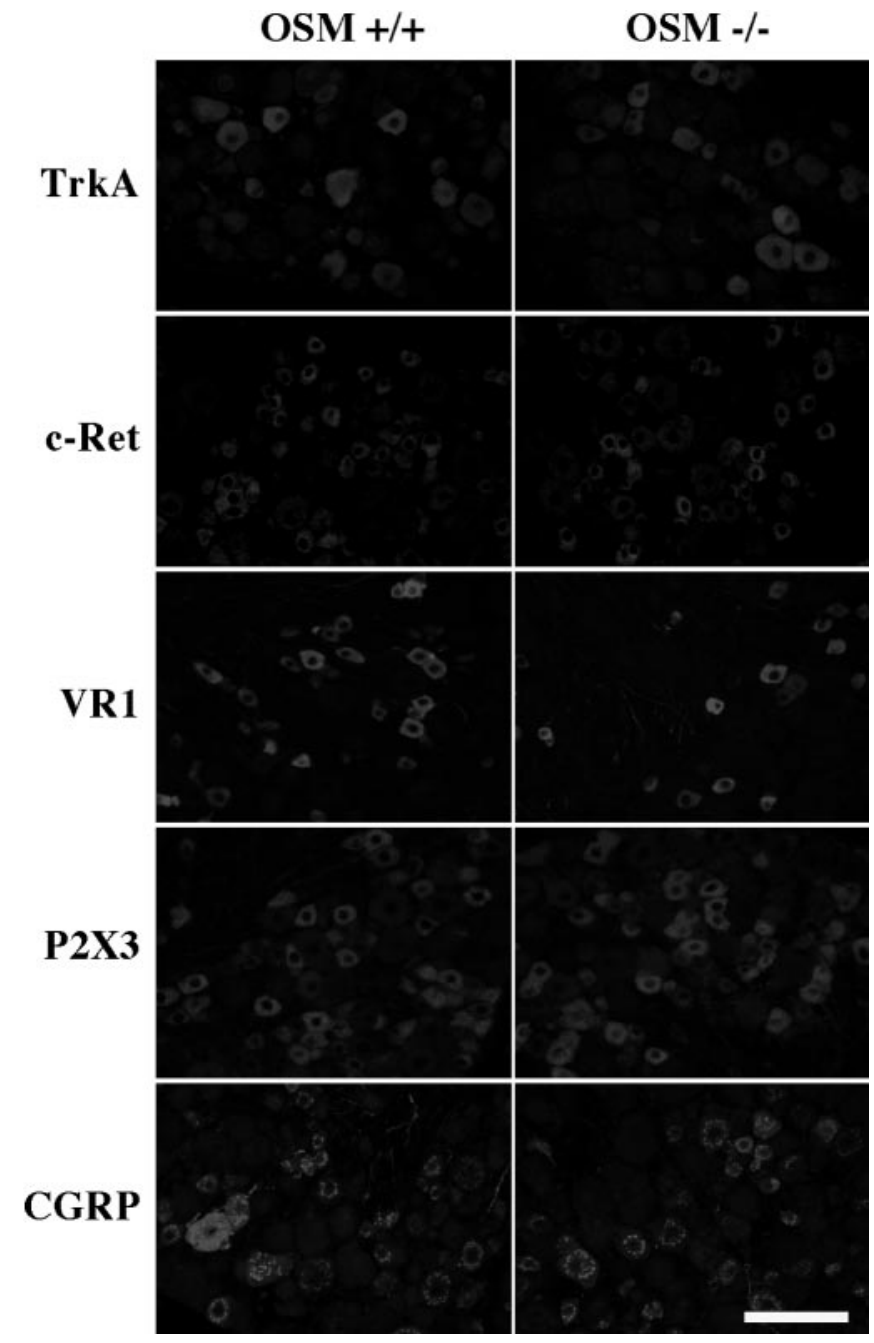

Figure 2. Expression of sensory neuronal markers in the DRGs of OSM ${ }^{-1-}$ mice. A series of sections through adult lumbar DRGs of OSM ${ }^{+/+}$and OSM ${ }^{-/-}$mice are shown. Scale bar, $100 \mu \mathrm{m}$.

P2X3-positive neurons were decreased, as shown in Figures 3 and 4. As expected, the capsaicin stimulus elicited robust licking of the paw in $\mathrm{OSM}^{+/+}$and $\mathrm{OSM}^{+/-}$mice, but $\mathrm{OSM}^{-/-}$mice showed significantly reduced behavioral responses to capsaicin (Fig. $6 A, B$ ). In addition, the pain behaviors (licking) evoked by a hindpaw injection of $\alpha \beta$-meATP (Fig. 6C) or formalin (Fig. 6D) were also significantly reduced in the $\mathrm{OSM}^{-1-}$ mice.

Next, we compared the thermoresponsive behavior of $\mathrm{OSM}^{+/+}$and OSM ${ }^{-/-}$mice, because VR1 has been proposed to be a sensor for noxious heat (Cao et al., 1998). The latency of response to an acute thermal stimulus was measured using a 52 or $58^{\circ} \mathrm{C}$ hot plate. $\mathrm{OSM}^{-1-}$ mice exhibited significantly longer response latencies than $\mathrm{OSM}^{+/+}$mice at both 52 and $58^{\circ} \mathrm{C}$ (Fig. $6 E$ ). In addition, the latency to respond to a more intense mechanical stimulus (tail clip) was also significantly prolonged in the $\mathrm{OSM}^{-1-}$ mice (Fig. $6 F$ ).

To determine whether the reduced pain responses in $\mathrm{OSM}^{-1-}$ mice were generalized to noxious stimulation of other tissues, we assessed acute visceral pain behavior evoked by the intraperitoneal injection of $\mathrm{MgSO}_{4}$, which produces an immediate visceral pain response (abdominal writhing) independent of inflammation, and injection of acetic acid, which induces pain secondary to an inflammatory reaction. OSM ${ }^{-1-}$ mice demonstrated a strik-
A
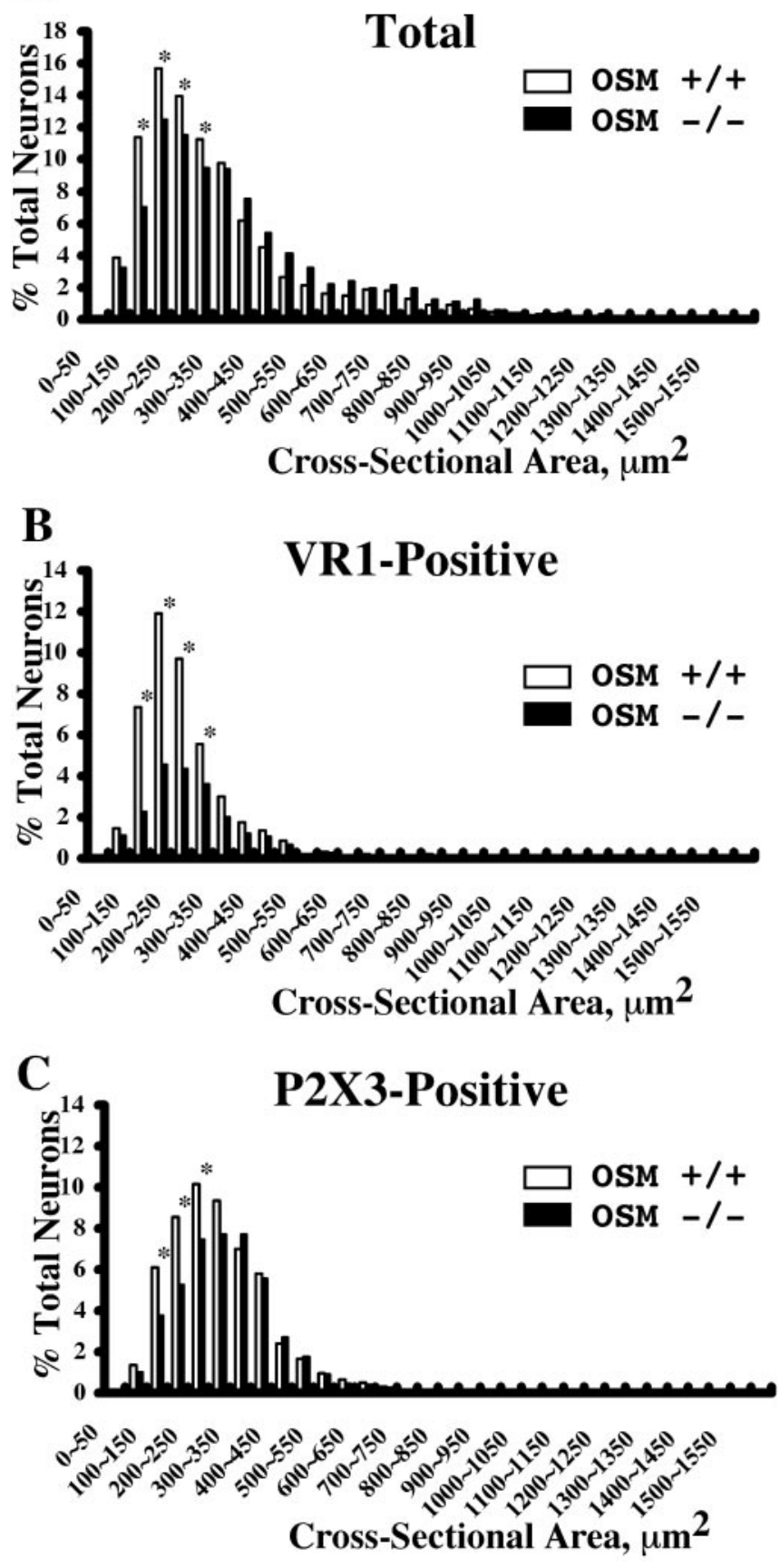

Figure 3. Size-frequency histograms illustrate the distribution of the cross-sectional areas of total ( $A$ ), VR1-positive ( $B$ ), and P2X3-positive (C) DRG neurons pooled from four $\mathrm{OSM}^{+/+}$and $\mathrm{OSM}^{-1-}$ mice. No significant differences were noted between the two genotypes except in the small-sized neurons $\left(<300 \mu \mathrm{m}^{2}\right) .{ }^{*} p<0.05 ; n=4$.

ing reduction in the number of abdominal writhes compared with wild-type in both tests of visceral pain (Fig. 6G,H).

Thus, behavioral acute nociceptive thresholds were affected markedly by an absence of OSM.

\section{Discussion}

The IL-6 family of cytokines plays important roles in a wide variety of biological systems by regulating cell growth and differentiation (Taga and Kishimoto, 1997; Heinrich et al., 1998). Among the members of this family, OSM and LIF are functionally and 


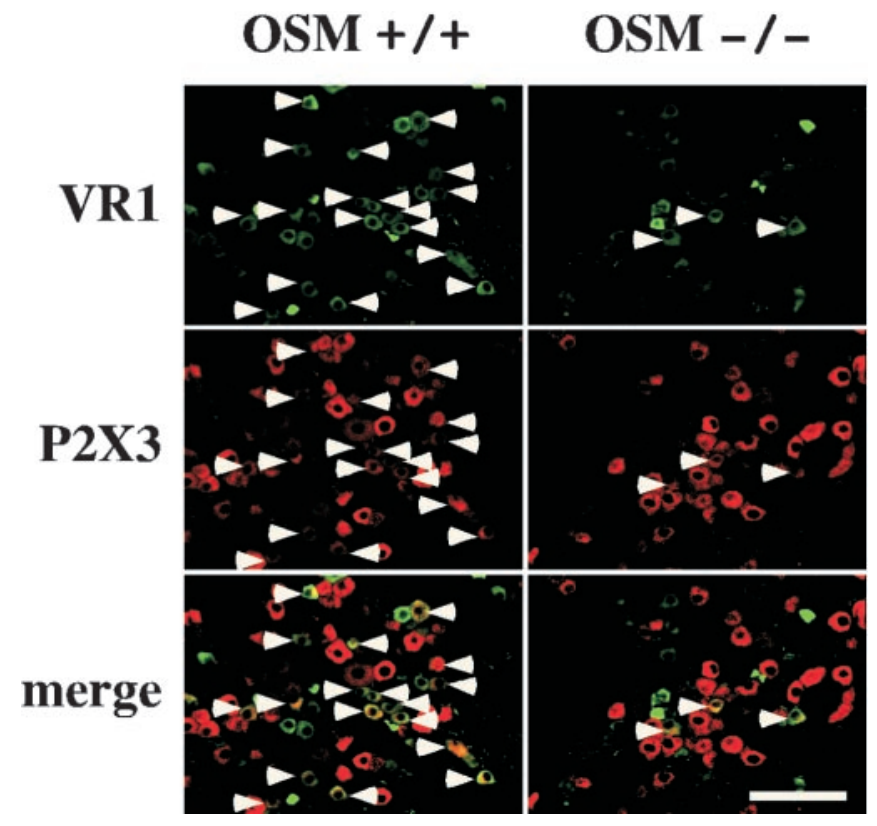

Figure 4. Double-immunofluorescence staining of VR1 and P2X3 in the adult DRG of $\mathrm{OSM}^{+/+}$(left) and OSM ${ }^{-1-}$ (right) mice. VR1/P2X3-double-positive cells (arrowheads) in the merged image are significantly reduced. Scale bar, $100 \mu \mathrm{m}$.

\section{OSM $+/+\quad$ OSM - / -}

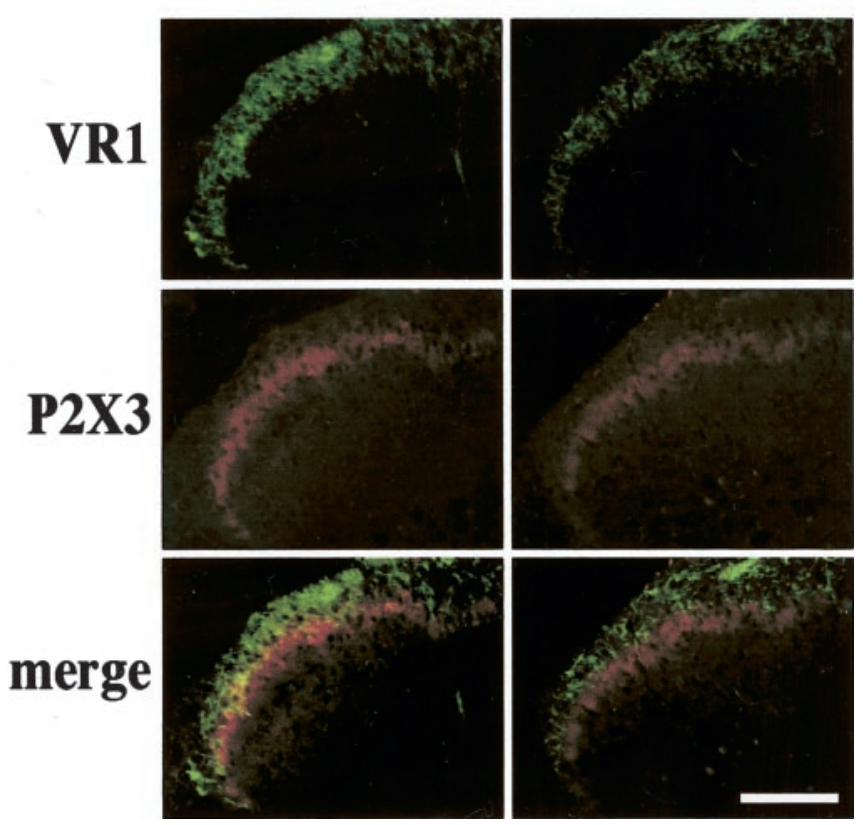

Figure 5. Double-immunofluorescence staining of VR1 and P2X3 in the dorsal horn of $\mathrm{OSM}^{+/+}$(left) and $\mathrm{OSM}^{-/-}$(right) adult mice. In OSM ${ }^{+/+}$mice, intense double immunoreactivity (yellow) is located in the inner portion of lamina ll of the dorsal horn. However, double immunostaining is almost completely absent from the dorsal horn of OSM ${ }^{-1-}$ mice. Scale bar, $200 \mu \mathrm{m}$.

structurally related, and their genes are tightly linked in the same chromosomal location (Gearing, 1993; Gearing et al., 1993; Jeffery et al., 1993). In both central and peripheral nervous systems, LIF has been reported to play some important roles: the potentiation of glial development, the differentiation of neural crest precursor cells into sensory neurons, and the switching of neuropeptide production in sympathetic neurons (Turnley and Bartlett,
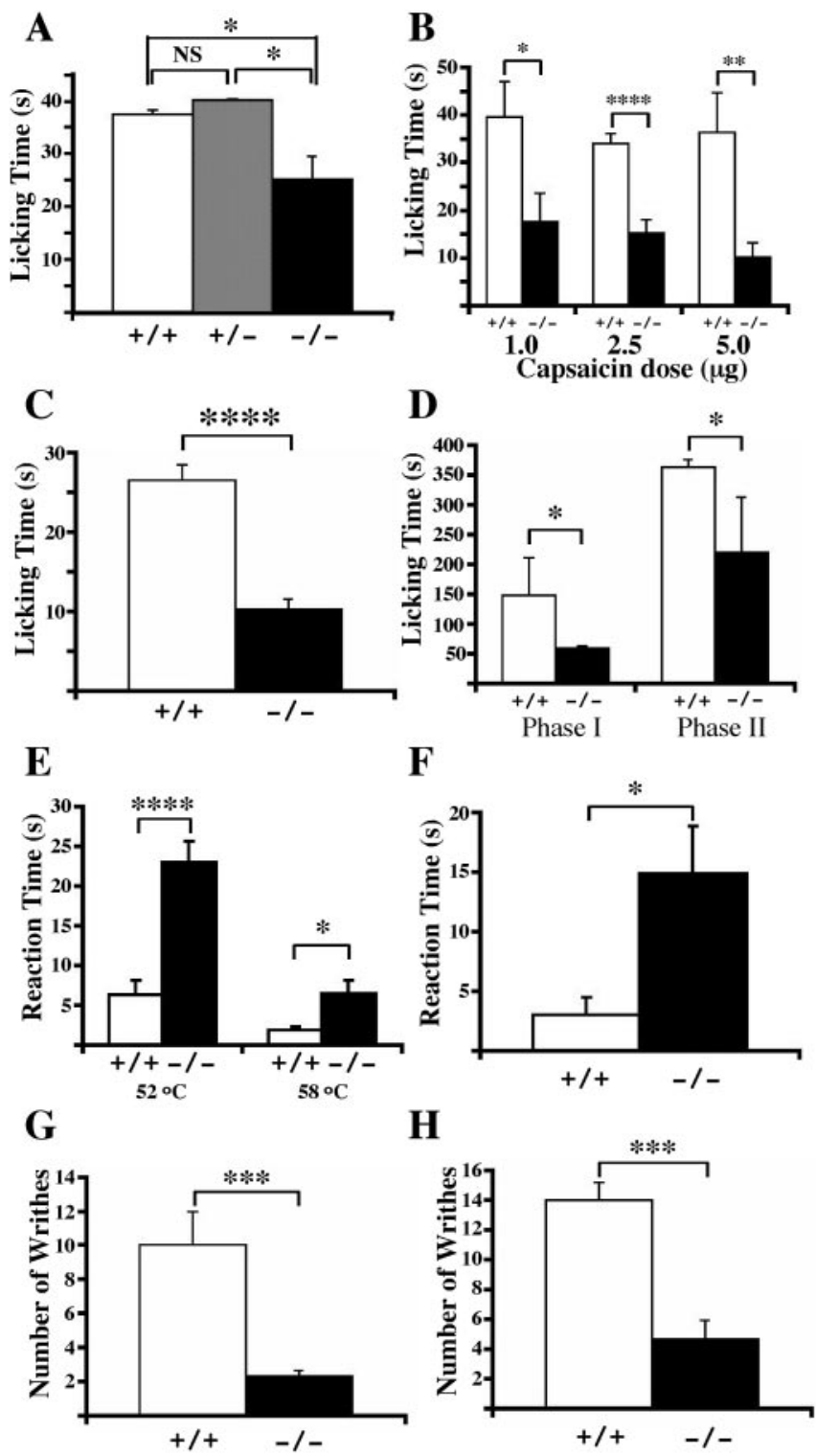

Figure 6. Reduced sensitivity to nociceptive stimuli in $0 \mathrm{SM}^{-1-}$ mice. $A-D$, Tests of chemical nociception. $A$, Duration of licking in response to intraplantar injection of capsaicin $(1.0 \mu \mathrm{g}$; $n=6$ ) is significantly reduced in mutant mice (black columns) compared with wild-type (white columns) and heterozygous mice (gray columns); the last two groups do not differ. $B$, Duration of licking in response to capsaicin at indicated doses $(n=5)$. C, Duration of licking in response to $\alpha \beta$-meATP $(n=6)$. D, Cumulative time spent licking the hindpaw after the subcutaneous injection of formalin $(n=6)$. Phase I, 0-10 min after injection; Phase II, 15-50 min after injection. $E$, Licking or jumping latency in the hot-plate assay $(n=6)$. $F$, Response latency to acute mechanical stimulus by tail clip $(n=6) . G, H$, Visceral pain responses (writhing) produced by the intraperitoneal injection of $\mathrm{MgSO}_{4}(G)$ or acetic acid $(H)(n=8-9$ for both wild-type and mutant). NS, Not significant. ${ }^{*} p<0.05 ;{ }^{* *} p<0.02$; ${ }^{* * *} p<0.01$; ${ }^{* * *} p<0.001$.

2000). However, the physiological function of OSM in the nervous system remains unknown.

Extensive studies on the neurotrophins during the development of DRG neurons have established that specific subsets of DRG neurons mediating different sensory modalities are supported by particular members of the neurotrophin family (Snider and Wright, 1996; Mogil et al., 2000). The majority of rodent DRG neurons, including all peptide-containing small-sized neurons, express TrkA and require nerve growth factor (NGF) for their survival during embryonic development. However, in half of the small-sized neurons (those that can bind the lectin isolectin 
B4), TrkA is downregulated during a few weeks after birth. These particular neurons change their expression of receptor tyrosine kinase from TrkA to c-Ret, suggesting a switch from NGF to glial cell line-derived neurotrophic factor (GDNF) responsiveness during postnatal development. It has been reported that LIF receptor starts to be expressed at an early embryonic stage (Qiu et al., 1994), and LIF and NGF synergistically induce the differentiation of mature sensory neurons from their precursors during early embryonic development (Murphy et al., 1993). In contrast, as described in the present study, OSMR-positive neurons began to appear at P0 and reached the adult level at P14, in the same manner as c-Ret expression. In addition, OSMR is expressed in the nonpeptidergic neurons (Tamura et al., 2003a), whereas LIF induces the differentiation to peptidergic neurons (Murphy et al., 1991, 1994). The distinct expression pattern of OSMR during development suggests that OSM may exert its function in concert with GDNF-family ligands.

Although LIF receptor was expressed in a variety of cells of the nervous system, no developmental abnormalities in the nervous system have been reported in $\mathrm{LIF}^{-1-}$ mice, which display female sterility attributable to defective blastocyst implantation, postnatal growth retardation, and defects in hematopoiesis and thymocyte proliferation (Escary et al., 1993). In OSM ${ }^{-1-}$ mice, VR1/ P2X3-double-positive neurons were significantly decreased. Although the exact mechanism is unclear, some possibilities may be considered. One is that OSM may modify the expression of VR1 and P2X3. It was reported that the expression of VR1 and $\mathrm{P} 2 \mathrm{X} 3$ in the DRGs increased by peripheral inflammation (Ji et al., 2002; Xu and Huang, 2002). In addition, OSM is produced by activated T cells, macrophages, polymorphonuclear neutrophils, and eosinophils, which participate in local inflammation (Modur et al., 1997; Grenier et al., 1999; Wallace et al., 1999; Tamura et al., $2002 \mathrm{~b})$. These findings suggest that OSM regulates the expression of VR1 and P2X3 in nociceptive neurons. Another possibility is that OSM may function as a postnatal survival factor to a specific subset of nociceptive neurons. In fact, the percentage of smallsized neurons to total DRG neurons was significantly reduced in $\mathrm{OSM}^{-1-}$ mice.

Consistent with histological results, the present study revealed that $\mathrm{OSM}^{-1-}$ mice displayed significantly reduced noxious responses in models of acute thermal, chemical, and visceral pain. Interestingly, a reduced response to mechanical pain was also observed in OSM ${ }^{-1-}$ mice, whereas $\mathrm{VR} 1^{-1-}$ or $\mathrm{P} 2 \mathrm{X} 3^{-1-}$ mice responded to mechanical pain normally (Caterina et al., 2000; Souslova et al., 2000). Although the mechanism remains unclear, OSM might play a role for the development of neurons responsive to mechanical stimuli.

Thus, our results indicate for the first time that OSM plays a key role for the postnatal stages of assembly of the neural pathways that detect noxious stimuli. Our data also suggest possible analgesic strategies based on the targeting of OSMR-positive neurons.

\section{References}

Banner LR, Patterson PH, Allchorne A, Poole S, Woolf CJ (1998) Leukemia inhibitory factor is an anti-inflammatory and analgesic cytokine. J Neurosci 18:5456-5462.

Cao YQ, Mantyh PW, Carlson EJ, Gillespie A-M, Epstein CJ, Basbaum AI (1998) Primary afferent tachykinins are required to experience moderate to intense pain. Nature 392:390-394.

Caterina MJ, Leffler A, Malmberg AB, Martin WJ, Trafton J, Petersen-Zeitz KR, Koltzenburg M, Basbaum AI, Julius D (2000) Impaired nociception and pain sensation in mice lacking the capsaicin receptor. Science 288:306-313.
Coggeshall RE (1992) A consideration of neural counting methods. Trends Neurosci 15:9-13.

Dickenson AH, Sullivan AF (1987) Peripheral origins and central modulation of subcutaneous formalin-induced activity of rat dorsal horn neurones. Neurosci Lett 83:207-211.

Elson GCA, Lelievre E, Guillet C, Chevalier S, Plun-Favreau H, Froger J, Suard I, de Coignac AB, Delneste Y, Bonnefoy J-Y, Gauchat J-F, Gascan H (2000) CLF associates with CLC to form a functional heteromeric ligand for the CNTF receptor complex. Nat Neurosci 3:867-872.

Escary JL, Perreau J, Dumenil D, Ezine S, Brulet P (1993) Leukaemia inhibitory factor is necessary for maintenance of haematopoietic stem cells and thymocyte stimulation. Nature 363:361-364.

Gearing DP (1993) The leukemia inhibitory factor and its receptor. Adv Immunol 53:31-58.

Gearing DP, Druck T, Huebner K, Overhauser J, Gilbert DJ, Copeland NG, Jenkins NA (1993) The leukemia inhibitory factor receptor (LIFR) gene is located within a cluster of cytokine receptor loci on mouse chromosome 15 and human chromosome 5p12-p13. Genomics 18:148-150.

Grenier A, Dehoux M, Boutten A, Arce-Vicioso M, Durand G, GougerotPocidalo M-A, Chollet-Martin S (1999) Oncostatin M production and regulation by human polymorphonuclear neutrophils. Blood 93:1413-1421.

Gundersen HJG, Bendtsen TF, Korbo L, Marcussen N, Moller A, Nielsen K, Nyengaard JR, Pakkenberg B, Sorensen FB, Vesterby A, West MJ (1988) Some new, simple and efficient stereological methods and their use in pathological research and diagnosis. Acta Pathol Microbiol Immunol Scand 96:379-394.

Hara T, Tamura K, de Miguel M, Mukouyama Y-S, Kim H-J, Kogo H, Donovan PJ, Miyajima A (1998) Distinct roles of oncostatin M and leukemia inhibitory factor in the development of primordial germ cells and Sertoli cells in mice. Dev Biol 201:144-153.

Heinrich PC, Behrmann I, Muller-Newen G, Schaper F, Graeve L (1998) Interleukin-6-type cytokine signaling through the gp130/Jak/STAT pathway. Biochem J 334:297-314.

Jeffery E, Price V, Gearing DP (1993) Close proximity of the genes for leukemia inhibitory factor and oncostatin M. Cytokine 5:107-111.

Ji R-R, Samad TA, Jin S-X, Schmoll R, Woolf CJ (2002) p38 MAPK activation by NGF in primary sensory neurons after inflammation increases TRPV1 levels and maintains heat hyperalgesia. Neuron 36:57-68.

Kamiya A, Kinoshita T, Ito Y, Matsui T, Morikawa Y, Senba E, Nakashima K, Taga T, Yoshida K, Kishimoto T, Miyajima A (1999) Fetal liver development requires a paracrine action of oncostatin $\mathrm{M}$ through the gp130 signal transducer. EMBO J 18:2127-2136.

Kishimoto T, Akira S, Narazaki M, Taga T (1995) Interleukin-6 family of cytokines and gp130. Blood 86:1243-1254.

Lecomte M-J, Basseville M, Landon F, Karpov V, Fauquet M (1998) Transcriptional activation of the mouse peripherin gene by leukemia inhibitory factor: involvement of STAT proteins. J Neurochem 70:971-982.

Matsui T, Kinoshita T, Morikawa Y, Tohya K, Katsuki M, Ito Y, Kamiya A, Miyajima A (2002) K-ras mediates cytokine-induced formation of E-cadherin-based adherens junctions during liver development. EMBO J 21:1021-1030.

Miyajima A, Kinoshita T, Tanaka M, Kamiya A, Mukouyama Y, Hara T (2000) Role of oncostatin M in hematopoiesis and liver development. Cytokine Growth Factor Rev 11:177-183.

Modur V, Feldhaus MJ, Weyrich AS, Jicha DL, Prescott SM, Zimmerman GA, McIntyre TM (1997) Oncostatin M is a proinflammatory mediator. In vivo effects correlate with endothelial cell expression of inflammatory cytokines and adhesion molecules. J Clin Invest 100:158-168.

Mogil JS, Yu L, Basbaum AI (2000) Pain genes? Natural variation and transgenic mutants. Annu Rev Neurosci 23:777-811.

Mosley B, De Imus C, Friend D, Boiani N, Thoma B, Park LS, Cosman D (1996) Dual oncostatin M (OSM) receptors: cloning and characterization of an alternative signaling subunit conferring OSM-specific receptor activation. J Biol Chem 271:32635-32643.

Mukouyama Y, Hara T, Xu M, Tamura K, Donovan PJ, Kim H, Kogo H, Tsuji K, Nakahata T, Miyajima A (1998) In vitro expansion of murine multipotential hematopoietic progenitors from the embryonic aorta-gonadmesonephros region. Immunity 8:105-114.

Murphy M, Reid K, Hilton DJ, Bartlett PF (1991) Generation of sensory neurons is stimulated by leukemia inhibitory factor. Proc Natl Acad Sci USA 88:3498-3501. 
Murphy M, Reid K, Brown MA, Bartlett PF (1993) Involvement of leukemia inhibitory factor and nerve growth factor in the development of dorsal root ganglion neurons. Development 117:1173-1182.

Murphy M, Reid K, Ford M, Furness JB, Bartlett PF (1994) FGF2 regulates proliferation of neural crest cells, with subsequent neuronal differentiation regulated by LIF or related factors. Development 120:3519-3528.

Qiu L, Bernd P, Fukada K (1994) Cholinergic neuronal differentiation factor (CDF)/leukemia inhibitory factor (LIF) binds to specific regions of the developing nervous system in vivo. Dev Biol 163:516-520.

Senaldi G, Varnum BC, Sarmiento U, Starnes C, Lile J, Scully S, Guo J, Elliott G, McNinch J, Shaklee CL, Freeman D, Manu F, Simonet WS, Boone T, Chang M-S (1999) Novel neurotrophin-1/B cell-stimulating factor-3: a cytokine of the IL-6 family. Proc Natl Acad Sci USA 96:11458-11463.

Snider WD, Wright DE (1996) Neurotrophins cause a new sensation. Neuron 16:229-232.

Souslova V, Cesare P, Ding Y, Akopian AN, Stanfa L, Suzuki R, Carpenter K, Dickenson A, Boyce S, Hill R, Nebenuis-Oosthuizen D, Smith AJ, Kidd EJ, Wood JN (2000) Warm-coding deficits and aberrant inflammatory pain in mice lacking P2X3 receptors. Nature 407:1015-1017.

Sugiura S, Lahav R, Han J, Kou S-Y, Banner LR de Pablo F, Patterson PH (2000) Leukaemia inhibitory factor is required for normal inflammatory responses to injury in the peripheral and central nervous systems in vivo and is chemotactic for macrophages in vitro. Eur J Neurosci 12:457-466.

Sun Y, Zigmond RE (1996) Leukaemia inhibitory factor induced in the sciatic nerve after axotomy is involved in the induction of galanin in sensory neurons. Eur J Neurosci 8:2213-2220.

Taga T, Kishimoto T (1997) Gp130 and the interleukin-6 family of cytokines. Annu Rev Immunol 15:797-819.

Tamura S, Morikawa Y, Tanaka M, Miyajima A, Senba E (2002a) Develop- mental expression pattern of oncostatin $\mathrm{M}$ receptor $\beta$ in mice. Mech Dev 115:127-131.

Tamura S, Morikawa Y, Miyajima A, Senba E (2002b) Expression of oncostatin $\mathrm{M}$ in hematopoietic organs. Dev Dyn 225:327-331.

Tamura S, Morikawa Y, Miyajima A, Senba E (2003a) Expression of oncostatin $\mathrm{M}$ receptor $\beta$ in a specific subset of nociceptive sensory neurons. Eur J Neurosci 17:2287-2298.

Tamura S, Morikawa Y, Senba E (2003b) Localization of oncostatin M receptor $\beta$ in adult and developing CNS. Neuroscience 119:991-997.

Tsuda M, Shigemoto-Mogami Y, Ueno S, Koizumi S, Ueda H, Iwanaga T, Inoue K (2002) Downregulation of P2X3 receptor-dependent sensory functions in A/J inbred mouse strain. Eur J Neurosci 15:1444-1450.

Turnley AM, Bartlett PF (2000) Cytokines that signal through the leukemia inhibitory factor receptor- $\beta$ complex in the nervous system. J Neurochem 74:889-899.

Wallace PM, MacMaster JF, Rouleau KA, Brown TJ, Loy JK, Donaldson KL, Wahl AF (1999) Regulation of inflammatory responses by oncostatin M. J Immunol 162:5547-5555.

Xu G-Y, Huang L-Y (2002) Peripheral inflammation sensitizes P2X receptormediated responses in rat dorsal root ganglion neurons. J Neurosci 22:93-102.

Yoshimura A, Ichihara M, Kinjyo I, Moriyama M, Copeland NG, Gilbert DJ, Jenkins NA, Hara T, Miyajima A (1996) Mouse oncostatin M: an immediate early gene induced by multiple cytokines through the JAK-STAT5 pathway. EMBO J 15:1055-1063.

Zarling JM, Shoyab M, Marquardt H, Hanson MB, Lioubin MN, Todaro GJ (1986) Oncostatin M: a growth regulator produced by differentiated histiocytic lymphoma cells. Proc Natl Acad Sci USA 83:9739-9743.

Zhong J, Dietzel ID, Wahle P, Kopf M, Heumann R (1999) Sensory impairments and delayed regeneration of sensory axons in interleukin-6deficient mice. J Neurosci 19:4305-4313. 